\title{
Community attitudes towards wildlife management in the Bolivian Chaco
}

\author{
Andrew J. Noss and Rosa Leny Cuéllar
}

\begin{abstract}
The process of community wildlife management in the Izozog area of the Bolivian Chaco began with participatory field research - self-monitoring of hunting activities and research on key game species. On-going discussions in community meetings have elicited seven wildlife management recommendations: (1) establishing hunting zones, (2) hunting only adults, (3) hunting only males during the reproductive season, (4) hunting only for the family's needs, (5) hunting only abundant animals, (6) protecting plants that are important to wildlife, and (7) prohibiting hunting by outsiders. We compare community attitudes towards these management measures. A majority of communities favour,
\end{abstract}

\section{Introduction}

Community wildlife management is increasingly widespread as an approach for conserving biodiversity through sustainable exploitation by indigenous peoples (Western \& Wright, 1994; Campos et al., 1996; Ortíz \& Mazzuchelli, 1997; Robinson \& Bennett, 2000). According to the context, the approach can benefit from cultural traditions with respect to stewardship and conservation ethic (Kleymeyer, 1994; Colchester, 2000; Schwartzman et al., 2000a). Traditional hunting practices such as taboos, exclusive hunting territories, and hunting zone rotation through trekking or distant camps may promote conservation and sustainable wildlife management (Redford \& Mansour, 1996; Bennett \& Robinson, 2000). At the same time, however, numerous studies indicate that indigenous peoples, just like people everywhere, act opportunistically in their economic self-interest in exploiting wildlife (Harcourt et al., 1986; Hames, 1987; Johnson, 1989; Mordi, 1991; Parry \& Campbell, 1992; Robinson \& Redford, 1994; Noss, 1997; De Boer \& Baquete, 1998; Redford \& Sanderson, 2000; Terborgh, 2000). Furthermore, changes in the physical, social, cultural and economic contexts of hunting activities undermine the sustainability of traditional systems (Redford \& Mansour, 1996; Bennett \& Robinson, 2000;

Andrew J. Noss (Corresponding author) WCS-Bolivia, Casilla 6272 , Santa Cruz, Bolivia. E-mail: anoss@infonet.com.bo

Rosa Leny Cuéllar Proyecto Kaa-lya, Casilla 6272, Santa Cruz, Bolivia Revised manuscript accepted for publication 4 June 2001 in decreasing order, measures 7, 4, 6 and 1, communities are divided with respect to measures 2 and 3, and most communities oppose measure 5. Two socio-economic characteristics of communities - location and ethnicity are associated with patterns of attitudes towards wildlife management among communities, whereas religion, economic activity and community size are not. Izoceño communities are currently reinterpreting traditional beliefs both to support and to oppose active wildlife management measures.

Keywords Bolivia, community wildlife management, hunting, indigenous peoples, perceptions.

Colchester, 2000). The following case study of the Izoceño people in the Bolivian Chaco investigates the current relationship between socio-economic factors and community attitudes towards wildlife management practices, and discusses the implications of these socioeconomic factors as well as inter-community differences in attitudes towards community wildlife management efforts by the Izoceño people.

\section{Background and study area}

The 23 Izoceño communities are located outside the Kaa-Iya del Gran Chaco National Park's western boundary (Fig. 1). The Izoceño people, represented by their traditional political organization the Capitanía del Alto y Bajo Izozog (CABI), have actively pursued wildlife conservation and management programmes since the early 1990s. They successfully lobbied for the creation in 1995 of the 3.5 million ha Kaa-Iya del Gran Chaco National Park, and the Bolivian government charged CABI with the administration of the protected area (Taber et al., 1997). The Wildlife Conservation Society (WCS) and the United States Agency for International Development (USAID) have supported CABI's conservation efforts in and around the protected area since 1996 through the Kaa-Iya Project (Painter \& Noss, 2000).

At the regional level, $\mathrm{CABI}$ strongly supports wildlife management programmes to demonstrate its continued capacity to co-administer the Kaa-Iya National Park. In addition the 1997 land reform law permitted the Izoceño people to claim an indigenous territory (TCO) of 
Fig. 1 Location of Izoceño communities and Kaa-Iya del Gran Chaco National Park, Santa Cruz Department, Bolivia (Izozog Zones 1-5 defined by Beneria-Surkin, 1998).

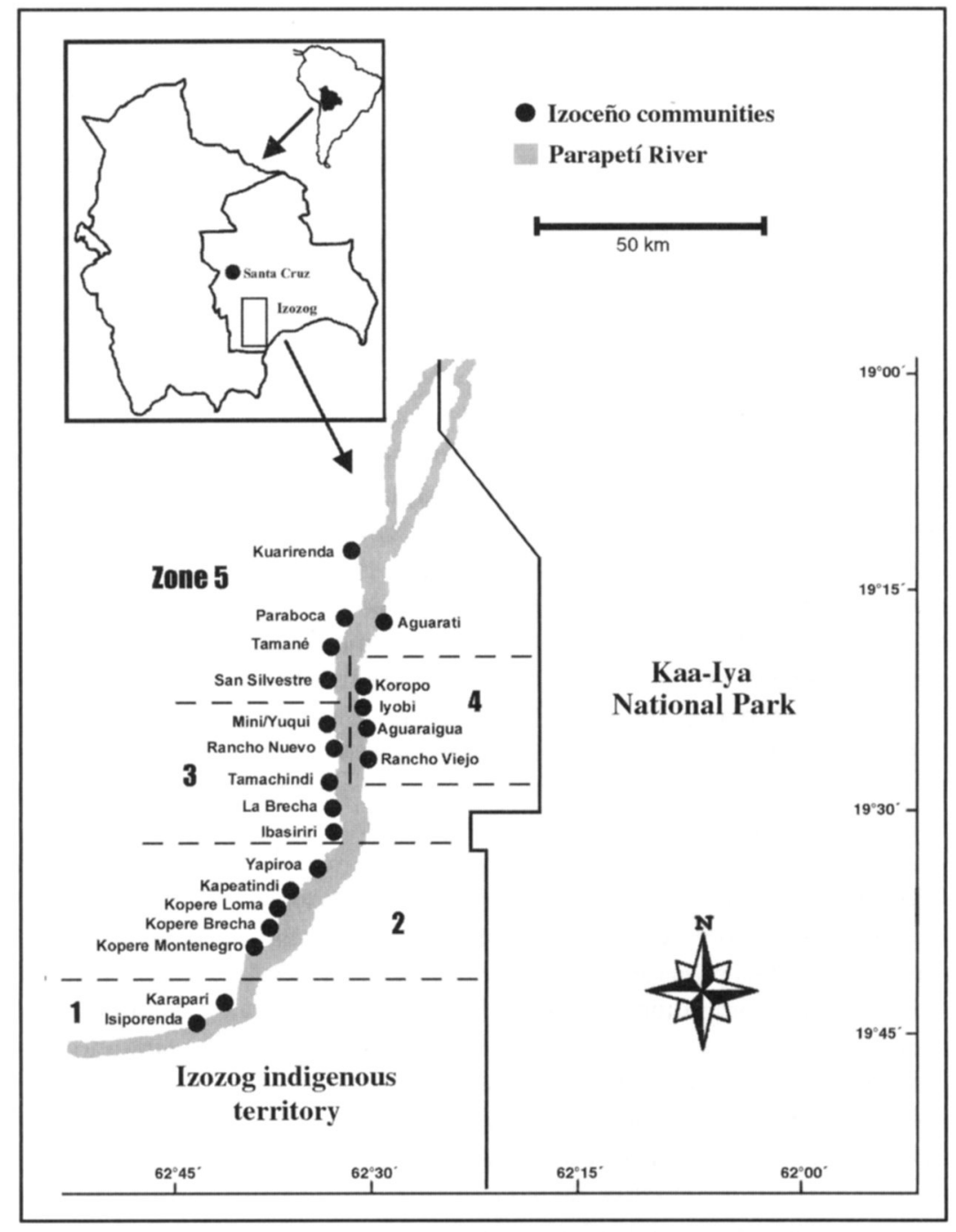

1.9 million ha, an area that is currently being titled. Within the TCO the Izoceños will have both the right and the responsibility to sustainably manage wildlife, and must produce formal management plans. Finally, the Bolivian government has begun to legalize, after a 10-year ban, commercial wildlife exploitation on a pilot basis for single species for particular land owners. The Izoceño people have demonstrated interest in producing commercial hunting proposals for the TCO for a number of species including parrots (Amazona aestiva and Myiopsitta monachus), tegu lizards Tupinambis rufescens, and collared peccaries Tayassu tajacu. Apart from these formal motivations, cultural objectives for participating in wildlife management activities should not be underestimated: to ensure that future generations of Izoceños are able to utilize wildlife resources (Redford \& Mansour, 1996), and to maintain natural resource use alternatives within the cultural and geographical space that the Izoceños are defending as they continually redefine their identity as a people (Schwartzman et al., 2000b)

\section{Methods}

\section{Participative research}

Similar to the community wildlife management work pioneered by Bodmer and colleagues in Peru (Bodmer \& Puertas, 2000), the Kaa-Iya Project has emphasized participative research as a basis for discussions with communities in order to collectively design and implement community wildlife management plans in the Izozog (Ayala, 2000; Painter \& Noss, 2000). The research activities, including hunter self-monitoring and biological studies of principal game species, are described in detail elsewhere (Noss, 1999; Cabrera et al., 2000; Guerrero et al., 2000). Hunter self-monitoring has identified the principal game species on which we 
subsequently focused species-specific biological studies. Although the Izoceños did not specifically define the objectives of biological research on species hunted for subsistence purposes, it provides the basis for CABI to produce the indigenous territory management plans that land titling requires. In the case of commercial exploitation, $\mathrm{CABI}$ and individual hunters specifically requested research by our team on parrots as the basis for a proposal that commercial hunting be legalized for these species.

\section{Community meetings}

In 1996 the Kaa-Iya project initiated a bi-annual series of meetings to inform the Izoceño public concerning project activities and discuss management issues in each of the 23 communities. Participation was voluntary. Although most Izoceños speak Spanish, all meetings were conducted in both Spanish and Guarani, with questions or responses translated as necessary. The bulk of the meetings were directed by Izoceño members of the Kaa-Iya project. We devoted time to presenting information and slides of our activities during the previous months, whenever possible having community members (monitors, parabiologists and hunters) who had been directly involved in the activities providing the explanations. The principal purpose of the meetings was to engage the communities in a discussion of wildlife management issues. In the series of meetings held in January and February 1998 we posed several open questions intended to elicit opinions and beliefs from the communities regarding wildlife and wildlife management: (a) what activities do you pursue? (b) what purpose does wildlife serve? (c) what problems does wildlife cause? and (d) is it possible to care for wildlife?

Supported by considerable data from the field research, the most recent meetings in November and December 1999 reviewed the wildlife management ideas proposed by the communities in the earlier meetings. For each proposal we provided concrete examples, from our experience with Izoceño hunters and from our field research on the game species, of what the management idea meant in practice and how it could be applied. In each community we asked which of these ideas were valuable and which were feasible in that hunters were willing to implement them to ensure that they and their children could continue hunting without causing wildlife species to disappear in the Izozog.

\section{Community characterization}

We attempted to understand the differences among communities in relation to proposed management measures by comparing responses expressed in the community meetings with a set of socio-economic characteristics describing the communities. BeneriaSurkin (1998) defines five geographical zones within the Izozog (Fig. 1) and provides three socio-economic factors that could account for differences in beliefs and practice relating to resource use among Izoceño communities: ethnicity, religion and economic activity. We further hypothesized that two additional factors, community size and location, could affect perceptions towards wildlife management. We present below a rough codification for each of the five factors. With respect to ethnicity and religion, the categorization is intended to emphasize the extremes as opposed to the large group of mixed communities. With respect to economic activity, community size, and location, the categorization is intended to create groups of roughly equivalent numbers of communities. Based on our knowledge of the Izozog and relevant literature, we predict how each factor would be expected to influence community attitudes towards wildlife management. Finally we present community responses to each of the management measures, and evaluate statistically the relationship between community attitudes and community socio-economic characteristics.

\section{Ethnicity}

The Izoceños can be divided into two ethnic groups: Guaraní and Karai or non-Guaraní. We categorized communities as (1) >80 per cent Guaraní, (2) mixed, and (3) $>80$ per cent Karai. Guaraní cultural traditions emphasize the role of kaa-iya spirit guardians, rather than humans, in conserving wildlife. In contrast, Karai beliefs view wildlife as a resource that can be managed in similar ways to domestic livestock. On this basis we predicted that Karai communities will favour active wildlife management.

\section{Religion}

Virtually all Izoceños affiliate themselves with either the Catholic church or the Protestant Evangelical church. We categorized communities as (1) $>80$ per cent Catholic, (2) mixed, or (3) $>80$ per cent Evangelical. The Catholic church, with its longer history in the Izozog, is more tolerant than Evangelical churches of traditional cultural beliefs and their respect for nature. In contrast, Evangelical churches emphasize humans' dominance over nature. On this basis we predicted that Evangelical communities will favour active wildlife management.

\section{Economic activity}

Although economic activity centres around agriculture and livestock, an important segment of the Izoceño population engages in seasonal migration to the sugar cane harvest (zafra) north of Santa Cruz. We categorized 
communities according to economic activity: (1) $>50$ per cent migration to the zafra, (2) 20-50 per cent migration, and (3) $<20$ per cent migration. Compared to permanent residents, seasonal migrants are more dependent on opportunistic hunting during the months when they reside in the Izozog and feel less long-term commitment to the community and its resources. On this basis we predicted that communities with a high proportion of seasonal migrants will oppose active wildlife management.

\section{Community size}

We also categorized communities according to size: (1) $<100$ inhabitants, (2) 100-300 inhabitants, and (3) >300 inhabitants. Small community size facilitates consensus for subsequent implementation and enforcement of management measures at the community level. On this basis we predicted that small communities will favour active wildlife management.

\section{Location}

The five geographical zones in Fig. 1 are distinguished primarily by their respective access to economic forces external to the Izozog (markets, hunting pressure, land pressure). On this basis we predicted that communities facing greater resource pressure from external forces will favour active wildlife management.

\section{Results}

During the January-February 1998 series of meetings we registered 1150 participants, 450 women and 700 men, and compiled a list of seven management proposals from all the communities (Table 1).

\section{Community wildlife management practices}

During the November-December 1999 meetings we registered 1010 participants - 365 women and 645 men. The communities provided three types of responses to each of the proposed management practices (Table 2): (1) explanations of how current hunting practices in fact represent management, (2) outright acceptance, and (3) outright rejection as impossible or irrelevant. Below we detail responses to each management proposal.

1) To establish hunting zones or a hunting rotation system We suggested two examples familiar to Izoceños: (1) the fallow system with crops, and (2) a community cattle project based on a rotational grazing system. Responses indicated that de facto temporal as well as spatial hunting rotation exists in the Izozog (the number of communities responding is in parentheses):

- from January-June water levels in the Parapetí river impede hunters from crossing to hunt on the opposite bank from their communities (8);

- from March-October emigration by 50-80 per cent of hunters to the sugar cane harvest near Santa Cruz reduces hunting pressure (4);

- from May-July the abundance of fish, as the Parapetí river is drying up, diverts potential hunters (2);

- from November-December the planting season interferes with hunting (1);

- hunters automatically rotate hunting zones, leaving areas to recover where they find little game and concentrating on areas where game is more abundant (3).

Communities opposed to this measure provided two reasons. Firstly, individual hunters have hunting zones where the kaa-iya (spirit guardians) consistently provide them with game, and hunting zone rotation is therefore impossible (five communities); if these hunters go elsewhere they will be unsuccessful, as will other hunters who enter these zones. Secondly, hunting rotation is unnecessary because the community's territory is relatively large for a small number of hunters (four communities).

2) To hunt only adult animals

In the case of brocket deer Mazama gouazoubira, peccaries (Tayassu pecari and T. tajacu) and tapir Tapirus terrestris, hunters can often distinguish juvenile from adult animals and could choose not to hunt young animals. Half the communities accepted outright to implement this management proposal. Others argued that they could not pass up any animal of these game species that they encountered because they may not find anything
Table 1 Management practices proposed by Izoceño communities.

\begin{tabular}{lll}
\hline Number & Summary & Proposal \\
\hline 1 & Zones & Establish hunting zones or a hunting rotation system \\
2 & Adults & Hunt only adult animals \\
3 & Males & Hunt only male animals when females are pregnant \\
4 & Need & Hunt only what the family needs without exaggerating \\
5 & Abundant & Hunt animals that are abundant and protect those that are rare \\
6 & Plants & Conserve plants that are important food sources for wildlife \\
7 & Outsiders & Prohibit hunting in the Izozog by outsiders \\
\hline
\end{tabular}


Table 2 Attitudes towards management practices and socio-economic characteristics by community.

\begin{tabular}{|c|c|c|c|c|c|c|c|c|c|c|c|c|}
\hline \multirow[b]{2}{*}{ Community } & \multicolumn{7}{|c|}{ Attitudes towards management practices } & \multicolumn{5}{|c|}{ Community characteristics } \\
\hline & $\begin{array}{l}\text { Zones } \\
\text { (1) }\end{array}$ & $\begin{array}{l}\text { Adults } \\
\text { (2) }\end{array}$ & $\begin{array}{l}\text { Males } \\
\text { (3) }\end{array}$ & $\begin{array}{l}\text { Need } \\
\text { (4) }\end{array}$ & $\begin{array}{l}\text { Abundant } \\
\text { (5) }\end{array}$ & $\begin{array}{l}\text { Plants } \\
\text { (6) }\end{array}$ & $\begin{array}{l}\text { Outsiders } \\
\text { (7) }\end{array}$ & Ethnicity & Religion & $\begin{array}{l}\text { Economic } \\
\text { activity }\end{array}$ & Size & Location \\
\hline Aguaraigua & 3 & 3 & 3 & 2 & 3 & 3 & 2 & 1 & 3 & 2 & 2 & 4 \\
\hline Aguarati & 3 & 2 & 3 & 3 & 3 & 1 & 2 & 2 & 1 & 1 & 2 & 5 \\
\hline Ibasiriri & 1 & 2 & 2 & 1 & 2 & 2 & 2 & 1 & 1 & 2 & 2 & 3 \\
\hline Isiporenda & 1 & 1 & 1 & 1 & 1 & 1 & 2 & 2 & 1 & 3 & 1 & 1 \\
\hline Iyobi & 3 & 3 & 3 & 1 & 3 & 1 & 2 & 1 & 3 & 2 & 3 & 4 \\
\hline Kopere Brecha & 1 & 3 & 3 & 1 & 3 & 1 & 2 & 1 & 1 & 1 & 2 & 2 \\
\hline Kopere Loma & 1 & 3 & 3 & 1 & 3 & 2 & 2 & 1 & 1 & 2 & 2 & 2 \\
\hline Kopere Montenegro & 3 & 1 & 1 & 1 & 3 & 1 & 2 & 1 & 1 & 3 & 1 & 2 \\
\hline Kapeatindi & 3 & 2 & 2 & 1 & 3 & 1 & 2 & 1 & 1 & 2 & 2 & 2 \\
\hline Karaparí & 1 & 3 & 3 & 1 & 2 & 1 & 2 & 1 & 1 & 3 & 1 & 1 \\
\hline Koropo & 3 & 1 & 3 & 3 & 3 & 1 & 2 & 1 & 3 & 2 & 2 & 4 \\
\hline Kuarirenda & 2 & 2 & 3 & 1 & 3 & 3 & 2 & 2 & 2 & 2 & 3 & 5 \\
\hline La Brecha & 1 & 2 & 2 & 1 & 2 & 1 & 2 & 1 & 2 & 2 & 3 & 3 \\
\hline Mini/Yuqui & 3 & 3 & 2 & 1 & 3 & 3 & 2 & 1 & 1 & 2 & 1 & 3 \\
\hline Paraboca & 3 & 3 & 1 & 1 & 2 & 2 & 2 & 3 & 1 & 3 & 1 & 5 \\
\hline Rancho Nuevo & 1 & 3 & 3 & 3 & 3 & 3 & 2 & 1 & 1 & 2 & 3 & 3 \\
\hline Rancho Viejo & 3 & 3 & 3 & 3 & 3 & 1 & 2 & 1 & 2 & 1 & 2 & 4 \\
\hline San Silvestre & 2 & 1 & 1 & 1 & 2 & 1 & 2 & 3 & 1 & 3 & 1 & 5 \\
\hline Tamachindi & 1 & 3 & 3 & 1 & 3 & 3 & 2 & 1 & 1 & 2 & 3 & 3 \\
\hline Tamané & 2 & 2 & 1 & 2 & 2 & 2 & 2 & 3 & 1 & 3 & 1 & 5 \\
\hline Yapiroa & 1 & 2 & 2 & 1 & 2 & 3 & 2 & 1 & 2 & 2 & 3 & 2 \\
\hline \multicolumn{13}{|c|}{ Per cent of all communities } \\
\hline Already practice & 43 & 19 & 24 & 71 & 5 & 52 & 0 & & & & & \\
\hline Accept & 14 & 33 & 24 & 10 & 33 & 19 & 100 & & & & & \\
\hline Reject & 43 & 48 & 52 & 19 & 62 & 29 & 0 & & & & & \\
\hline
\end{tabular}

Notes: Attitudes towards management practices: $1=$ already do, $2=$ accept, $3=$ reject.

Ethnicity: $1=>80$ per cent Guarani, $2=$ mixed, $3=>80$ per cent Karai (non-Guaraní).

Religion: $1=>80$ per cent Catholic, $2=$ mixed, $3=>80$ per cent Evangelical.

Economic activity: $1=>50$ per cent seasonal migrants to zafra (sugar cane harvest), $2=20-50$ per cent, $3=<20$ per cent.

Size: $1=<100$ inhabitants, $2=100-300,3=>300$.

Location: see Zones 1-5 in Fig. 1 (Beneria-Surkin, 1998).

else that day, or even that the kaa-iya who provided the animal would punish them for rejecting the gift.

3) To hunt only male animals when females are pregnant All hunters recognize the sharply defined reproductive season for armadillos (August-October). Ten communities indicated that their current practice is not to hunt armadillos at all from August to March because they are not fat and the females are almost all pregnant. In addition, one community added that they do not hunt chachalacas Ortalis canicollis (Cracidae) during the season when they are nesting. One community pointed out that the reproductive period for many animals coincides with the sugar cane harvest when many hunters are absent from the community. However, others repeated that they hunt in order to put meat on their tables, and could not pass up game animals that they encountered.

4) To hunt only what the family needs

White-lipped peccaries Tayassu pecari form herds of 30 or more individuals, offering hunters the opportunity to kill several animals at once. Everyone responded that all Izoceños hunt only to satisfy the needs of their family, although in some cases meaning one or two animals, and in others three or more. Two communities suggested that if surplus animals were killed the meat could be exchanged for other food items or shared with extended family.

5) To hunt animals that are abundant and relatively resilient to hunting pressure (brocket deer, collared peccary, ninebanded armadillo Dasypus novemcinctus, chachalaca) and protect those that are rare or vulnerable (primates, guanaco Lama guanicoe, Chacoan peccary Catagonus wagneri, tapir, white-lipped peccary, three-banded armadillo

Tolypeutes matacus)

Again, communities disagreed about what was appropriate and feasible. Those rejecting this proposal reiterated their need for meat and their obligation to accept any gift from the kaa-iya, or argued that no species have declined, although animals may have moved further away from communities. On the other hand, six 
communities recognized that certain species have become less abundant during the past few decades, and accepted to not hunt animals that they rarely encounter anyway - Chacoan peccary, tapir and white-lipped peccary. All accepted to not hunt guanacos, whose very restricted distribution ensures that they are seldom encountered. In addition, because they do not consider the meat to be edible, no Izoceños hunt any of the three species of primates frequently encountered near the communities: black howler monkey Alouatta caraya, titi monkey Callicebus moloch and night monkey Aotus azarae.

\section{6) To conserve plants that are important food sources for wildlife \\ Prosopis chilensis (Leguminosae) and Ziziphus mistol} (Rhamnaceae) are two tree species that produce fruits favoured by many animals, but they are also exploited for lumber. The three communities that accepted this proposal said that they exploit for lumber alternative trees that are not such important fruit producers: Schinopsis cornuta (Anacardiaceae), Aspidosperma quebracho blanco (Apocynaceae), Maclura tinctoria (Moraceae), Diplokeleba floribunda (Sapindaceae) and Phyllostylon rhamnoides (Urticaceae). Two other communities claimed that fruiting tree species are not used for lumber, or are harvested selectively based on their form and lower quality of fruit. Finally, five communities pointed out that people no longer consume wild fruits, and that game is hunted away from the river, whereas Prosopis trees in particular are concentrated along the river, thereby reducing competition between humans and wildlife for these resources.

\section{7) To prohibit hunting in the Izozog by outsiders}

Sport hunters from neighbouring towns and cities such as Charagua, Camiri and Santa Cruz travel as far as the Izozog on weekend or holiday hunting outings. Commercial hunters also enter the Izozog to collect the turquoise-fronted parrot Amazona aestiva and several other species of marketable birds. All the communities agreed with this proposal and asked for action by CABI at the regional level with support from the national park and the national land titling institute.

With respect to measures already practised, over twothirds of communities claim that they hunt only what they need, and one half conserves useful plants (Table 2). Combining what communities already practice with measures they accept to implement, the favoured management practices, in decreasing order, are the following: prohibit the entry of outsiders, hunt according to one's needs, conserve useful plants, and establish hunting zones or a rotation (Table 2). Only about half the communities favour hunting only adult or only male animals. Finally, the least popular measure, with one-third of communities in favour, is to hunt only abundant animals.

\section{Attitudes towards wildlife management and community characteristics}

Using our method of categorizing socio-economic characteristics into intervals, two of our five predictions regarding community attitudes towards wildlife management held, one factor was significant but contrary to our prediction, and two predictions did not hold. The Kruskall-Wallis $H$-test ( $\mathrm{df}=2, \alpha<0.05$ ) suggests that an association exists between ethnicity and support for two management measures: Karai communities favour active management in the form of measure 1 - the establishment of hunting zones $(H=5.05)$ - and measure 2 - the prohibition on hunting juvenile animals $(H=5.53)$. A significant association ( $\mathrm{df}=4, \alpha<0.01, H<-27.45$ ) also exists between location and each of the management measures tested except the prohibition of hunting in the Izozog by outsiders, which is a measure that was supported by all communities. As we had predicted, communities facing greater pressure from external forces support active management measures. Although religion is a significant factor influencing support for active management, contrary to our prediction, predominantly Catholic rather than Evangelical communities support measure 6 - the conservation of important plants $(H=5.07)$. According to this statistical analysis, economic activity and community size are not associated with patterns of attitudes towards management measures. Two predictions did not hold: that communities with a higher proportion of seasonal migrants would oppose active management measures, and that small communities would support active management measures.

\section{Discussion}

The data supported our prediction that Karai communities will favour active wildlife management, but only with respect to two of the seven management measures. Guaraní cultural traditions described by Riester (1984) and Combès et al. (1998) emphasize the role of the $k a a-i y a$ as spirit guardians responsible for managing each species of wild animal. These beliefs are similar to those of other indigenous groups in South America, for example the Embera in Colombia (Torgler et al., 1998), the Siona-Secoya of Ecuador (Vickers, 1994) and the Kuna in Panama (Ventocilla et al., 1996).

Rather than strictly determining community attitudes towards wildlife in the Izozog, traditional beliefs are continuously reinterpreted according to people's experience with changing environmental and socio-economic 
conditions (Geertz, 1973; Schwartzman et al., 2000b). In Karai communities elements of the traditional belief system are interpreted in support of active conservation measures. Hunters must ask permission of the kaa-iya to hunt in an area, showing respect for the kaa-iya and the wildlife in the area. Hunters are not to hunt juvenile animals, mistreat animals (allowing injured animals to escape), hunt more than a family needs (one or two animals), or cause disturbances, for example making noise by hunting with firearms or dogs (Combès et al., 1998). These elements of rational sustainable exploitation are reflected in management practices 2 and 4 proposed by the communities and can form the basis for further scientific and active management (Ulloa et al., 1996; Bennett \& Robinson, 2000). Karai communities, perhaps because they depend to a greater degree on active livestock management, more readily extend their attitudes towards management from livestock to wildlife. They consider wildlife to be a limited resource that has been depleted in certain areas of the Izozog because of excessive or indiscriminate hunting practices, in other words because hunters are violating the kaa-iya's prohibitions. Furthermore they argue that while God (or the $k a a-i y a)$ provides wildlife, people can care for that which God or the kaa-iya provides.

In contrast, the Guaraní communities at present tend to interpret traditional beliefs in opposition to active management: animals encountered are gifts that cannot be rejected (even if they are juvenile, female, pregnant, rare or diseased), and the kaa-iya will ensure that wildlife is not exterminated. Rare species are therefore ones that the kaa-iya is protecting by keeping in a distant place or by not allowing hunters to encounter them. In the past hunting for the family's needs may have meant meat for dinner, but now may mean earning a steady income from commercial hunting. Likewise none but the oldest hunters would consider firearms or dogs to be inappropriate noise in a hunting area, since they know no other hunting techniques. Enforcement of the prohibitions is also the domain of the kaa-iya rather than the community: in addition to failing to provide game, the kaa-iya can frighten, harm, kill or steal the spirit of a recalcitrant hunter. This theistic view of nature produces passivity in wildlife management: wildlife populations are controlled by supernatural beings and therefore human action is futile (Mordi, 1991). Supernatural control coincides with the belief that wildlife resources are infinite, again a view shared by numerous indigenous groups (Johnson, 1989; Mordi, 1991).

Although a statistically significant relationship exists between religion and support for active wildlife management, contrary to our prediction predominantly Catholic communities favour active wildlife manage- ment in the case of measure 6, the conservation of important plants. This result may derive from a Catholic emphasis on community cohesion, whereas Protestant emphasis on individual accumulation and God's inexhaustible bounty may undermine resource management by the community. The relationship between religion and support for wildlife management measures, however, remains unclear in the lzozog. Religious affiliation among Izoceños is exceedingly fluid with many individuals participating in events held by both denominations. We did not identify any explicit differences among these two Christian religious groups in the Izozog with respect to doctrine regarding wildlife exploitation. However, similar to the malleability of kaa-iya beliefs in the Izozog, Christian tradition has been widely interpreted both to undermine conservation humans' God-given right and religious duty to dominate nature (White, 1967) - and to support stewardship, with humans accountable for conserving nature (Barr, 1972; Ehrenfeld, 1988; Baker, 1996).

Finally the data support our expectation that communities facing greater resource pressure from external forces will favour active wildlife management. This is in accordance with research elsewhere indicating that support for active management is more likely to exist among communities experiencing resource scarcity (Redford \& Mansour, 1996). The southernmost Izoceño communities, Zones 1 and 2, are distinguished by their proximity to colonies established in the past 5-10 years by farmers of German Mennonite descent immigrating to Bolivia from Paraguay, Mexico and Belize (BeneriaSurkin, 1998). The Mennonite colonies represent a recent and strong pressure on natural resources, converting vast areas of former forested hunting zones to clearcut intensive farming. Zone 1 and 2 communities also experience the most constant access to and from population centres outside the Izozog. The northernmost Izoceño communities, Zones 4 and 5, also face competition from non-Izoceños for land and natural resources, but from ranching rather than farming properties.

Natural resource use in the Izozog results from a combination of opportunism on one hand, and response to environmental and socio-economic pressures on the other hand. Current belief systems grow out of agricultural production systems (irrigated farming and smallscale livestock) organized at the family and, to a lesser degree, community levels. With an area of only 78,000 ha currently titled to the 8000 inhabitants of the Izozog, wildlife remains on the periphery in people's perceptions of managed resources. The impending titling of an indigenous territory exceeding 1.9 million ha brings the Izoceños to a critical turning point as they must begin to manage the entire territory and develop production systems at this scale, where wildlife and 
other natural resources will necessarily become explicit objects of management.

The first wildlife management measure unanimously accepted by all communities is to prohibit the entry of non-Izoceño hunters to the Izozog. This type of measure does not incur direct costs for Izoceños, and for this reason received unanimous support among the communities. More importantly, controlling the Izoceño territory's boundaries is fundamental for any further management measures inside the territory: competition with outside hunters reduces options and alters priorities in resource use. Implementing this measure could unify Izoceños to take action with respect to wildlife management at the scale of the territory as a whole.

The preceding analysis suggests that two socioeconomic characteristics of Izoceño communities, namely location and ethnicity, influence community attitudes towards wildlife management measures. The role of a third characteristic, religion, is unclear. It appears that community size and economic activity do not influence community attitudes. This knowledge will permit us to adapt future community discussions and activities, advancing more rapidly towards implementation of community wildlife management plans in those communities facing greater external pressure on wildlife resources. Finally, predominantly Karai communities provide concrete local examples for discussing appropriate forms of integrating traditional and 'scientific' management principles in other communities less supportive of active wildlife management.

\section{Acknowledgements}

This publication was made possible by financial support from the United States Agency for International Development (USAID, Cooperative Agreement no. 511-A-0001-00005). The opinions expressed are those of the authors and do not necessarily represent the criteria of USAID. We thank the communities of the Izozog for their participation and support. We thank Michael Painter, Gery Ryan and four anonymous reviewers for their constructive comments.

\section{References}

Ayala, W. (2000) La participación de los comunarios izoceños en el manejo de fauna. In Manejo de Fauna Silvestre en Amazonía y Latinoamérica (eds E. Cabrera, C. Mercolli and R. Resquín), pp. 529-534. Fundación Moises Bertoni, Asunción, Paraguay.

Baker, B. (1996) A reverent approach to the natural world. Bioscience, 46, 475-478.

Barr, J. (1972) Man and nature: the ecological controversy and the Old Testament. Bulletin of the John Rylands Library, 55, 9-32.
Beneria-Surkin, J. (1998) Socio-Economic Study of Five Izoceño Communities. Technical Paper \#6. Kaa-Iya Project, Santa Cruz, Bolivia.

Bennett, E.L. \& Robinson, J.G. (2000) Hunting for sustainability: the start of a synthesis. In Hunting for Sustainability in Tropical Forests (eds J. G. Robinson and E. L. Bennett), pp. 499-519. Columbia University Press, New York, USA.

Bodmer, R. \& Puertas, P.E. (2000) Community-based comanagement of wildlife in the Peruvian Amazon. In Hunting for Sustainability in Tropical Forests (eds J. G. Robinson and E. L. Bennett), pp. 395-409. Columbia University Press, New York, USA.

Cabrera, E., Mercolli, C. \& Resquín, R. (eds) (2000) Manejo de Fauna Silvestre en Amazonía y Latinoamérica. Fundación Moises Bertoni, Asunción, Paraguay

Campos, C., Ulloa, A. \& Torgler, H.R. (eds) (1996) Manejo de Fauna con Comunidades Rurales. Fundación Natura, Bogotá, Colombia.

Colchester, M. (2000) Self-determination or environmental determinism for indigenous peoples in tropical forest conservation. Conservation Biology, 14, 1365-1367.

Combès, I., Justiniano, N., Segundo, I., Vaca, D., Vaca, R., Yandura, A. \& Yandura, J. (1998) Kaa Iya Reta: los Dueños del Monte. Technical Paper \#40. Kaa-Iya Project, Santa Cruz, Bolivia.

De Boer, W.F. \& Baquete, D.S. (1998) Natural resource use, crop damage and attitudes of rural people in the vicinity of the Maputo Elephant Reserve, Mozambique. Environmental Conservation, 25, 208-218.

Ehrenfeld, D.W. (1988) Why put a value on biodiversity? In Biodiversity (eds E. O. Wilson and F. M. Peter), pp. 212-216. National Academy Press, Washington DC.

Geertz, C. (1973) The Interpretation of Cultures. Basic Books, New York, USA.

Guerrero, M.J., Arambiza, A., González, L. \& Ity, E. (2000) Contribución al Conocimiento de los Psittacidae Sometidos a Caceria por Comunidades Guaranies-izoceñas y Propuestas para su Conservación, Izozog, Provincia Cordillera, Santa Cruz, Bolivia. Technical Paper \#62. Kaa-Iya Project, Santa Cruz, Bolivia.

Hames, R. (1987) Game conservation or efficient hunting? In The Question of the Commons: The Culture and Ecology of Communal Resources (eds B. J. McCay and J. M. Acheson), pp. 92-107. University of Arizona, Tucson, AZ, USA.

Harcourt, A., Pennington, H.H. \& Weber, A.W. (1986) Public attitudes to wildlife and conservation in the Third World. Oryx, 20, 152-154.

Johnson, A. (1989) How the Machiguenga manage resources: conservation or exploitation of nature? In Resource Management in Amazonia: Indigenous and Folk Strategies (eds D. A. Posey and W. Balée), pp. 213-222. New York Botanical Garden, New York, USA.

Kleymeyer, C.D. (1994) Cultural traditions and communitybased conservation. In Natural Connections: Perspectives in Community-Based Conservation (eds D. Western and R. M. Wright), pp. 323-336. Island Press, Washington DC, USA.

Mordi, A.R. (1991) Attitudes Toward Wildlife in Botswana. Gartland, New York, USA.

Noss, A.J. (1997) Challenges to nature conservation with community development in central African forests. Oryx, 31, 180-188. 
Noss, A. (1999) Manejo de fauna comunitario en el Gran Chaco, Bolivia. In Manejo y Conservación de Fauna Silvestre en América Latina (eds O. L. Montenegro, R. E. Bodmer and T. G. Fang), pp. 109-116. Instituto de Ecología, La Paz, Bolivia.

Ortíz, B. \& Mazzuchelli, S. (eds) (1997) Evaluating Eden: Community Wildlife Management. IUCN/IIED, Quito, Ecuador/Buenos Aires, Argentina.

Painter, M. \& Noss, A. (2000) La conservación de fauna con organizaciones comunales: experiencia con el pueblo Izoceño de Bolivia. In Manejo de Fauna Silvestre en Amazonía y Latinoamérica (eds E. Cabrera, C. Mercolli and R. Resquín), pp. 167-180. Fundación Moises Bertoni, Asunción, Paraguay.

Parry, J. \& Campbell, B. (1992) Attitudes of rural communities to animal wildlife and its utilization in Chobe Enclave and Mababe Depression, Botswana. Environmental Conservation, 19, 245-252.

Redford, K.H. \& Mansour, J.A. (eds) (1996) Traditional Peoples and Biodiversity Conservation in Large Tropical Landscapes. Nature Conservancy, Washington DC, USA.

Redford, K.H. \& Sanderson, S.E. (2000) Extracting humans from nature. Conservation Biology, 14, 1362-1364.

Riester, J. (1984) Textos Sagrados de los Guaranies en Bolivia: una Cacería en el Izozog. Los Amigos del Libro, La Paz, Bolivia.

Robinson, J.G. \& Bennett, E.L. (eds) (2000) Hunting for Sustainability in Tropical Forests. Columbia University Press, New York, USA.

Robinson, J.G. \& Redford, K.H. (1994) Community-based approaches to wildlife conservation in Neotropical forests. In Natural Connections: Perspectives in Community-Based Conservation (eds D. Western and R. M. Wright), pp. 300-319. Island Press, Washington DC, USA.

Schwartzman, S., Moreira, A. \& Nepstad, D. (2000a) Rethinking tropical forest conservation: perils in parks. Conservation Biology, 14, 1351-1357.

Schwartzman, S., Nepstad, D. \& Moreira, A. (2000b) Arguing tropical forest conservation: people versus parks. Conservation Biology, 14, 1370-1374.

Taber, A., Navarro, G. \& Arribas, M.A. (1997) A new park in the Bolivian Gran Chaco - an advance in tropical dry forest conservation and community-based management. Oryx, 31, 189-198.
Terborgh, J. (2000) The fate of tropical forests: a matter of stewardship. Conservation Biology, 14, 1358-1361.

Torgler, H.R., Ulloa, A. \& Torgler, M.R. (1998) Tras las Huellas de los Animales: 23 Especies del Chocó Biogeográfico. Fundación Natura, Bogotá, Colombia.

Ulloa, A., Torgler, H.R. \& Campos, C. (1996) Conceptos y metodologías para la preselección y análisis de alternativas de manejo de fauna de caza con indígenas embera en el Parque Nacional Natural Utría, PNNU, Chocó, Colombia. In Manejo de Fauna con Comunidades Rurales (eds C. Campos, A. Ulloa and H. R. Torgler), pp. 19-48. Fundación Natura, Bogotá, Colombia.

Ventocilla, J., Núñez, V., Herrera, H., Herrera, F. \& Chapin, M. (1996) The Kuna Indians and conservation. In Traditional Peoples and Biodiversity Conservation in Large Tropical Landscapes (eds K. H. Redford and J. A. Mansour), pp. 33-56. The Nature Conservancy, Washington DC, USA.

Vickers, W.T. (1994) From opportunism to nascent conservation: the case of the Siona-Secoya. Human Nature, 5, 307-337. Western, D. \& Wright, R.M. (eds) (1994) Natural Connections: Perspectives in Community-based Conservation. Island Press, Washington DC, USA.

White, L.W. (1967) The historical roots of our ecological crisis. Science, 155, 1203-1207.

\section{Biographical sketches}

Andrew Noss has worked for the Wildlife Conservation Society in the Izozog since 1996. Rosa Leny Cuéllar has worked for the Capitanía del Alto y Bajo Izozog since 1997. Together and within the USAID-funded Kaa-Iya Project, they have developed a community wildlife management programme with the 23 communities and 8000 inhabitants of the Izozog. The programme reflects their research interests in combining hunter self-monitoring with research on primary game species and community-level activities in order to promote sustainable wildlife exploitation in indigenous territories. 